\title{
University-Led Routes of Initial Teacher Training in Great Britain
}

\author{
Dernova M., Perevozniuk V. * \\ Kremenchuk Mykhailo Ostrohradskyi National University, Kremenchuk, Ukraine
}

Received: $12.11 .2018 \quad$ Accepted: 28.12 .2018

\begin{abstract}
The paper studies the modern system of initial teacher training (ITT) in the UK, which is quite diversified due to the large number of educational programs leading to awarding the qualified teacher status (QTS). On the macro level, the authors identify three main trajectories of ITT for primary and secondary schools, in particular: university-led, school-led and school-HE-led. On the micro level, the authors explore the university-led ITT, which offers educational programs at the first and second levels of teacher training, in particular: BEd, BA and BSC programs, BA and BSc with opt-in QTS, PGCE/PGDE programmes, subject conversion PGCE and integrated Master with opt-in QTS. The paper also presents requirements for admission to the first and second level programs. The analysis of British universities' teacher training programs has also allowed to identify three types of flexible ITT programs at the second level, among them are flexible, part-time and distance programs for PGCE/PGDE. It is noted that for those people over the age of 21 years and those who apply for one of the flexible programs, there is a system of recognition of previous learning and experience. Analysing Ukrainian and foreign studies in British ITT the authors have found that various aspects of the problem were payed attention to, but the current ITT programs, which have appeared in the last few years, were not discussed, since the British education system is constantly transforming to meet changing needs of society. The study results in refining the modern ITT university-led trajectory in the UK. Under the refinement the authors suggest newly introduced opt-in QTS programmes (BA and BSc opt-in QTS, MA opt-in QTS) to be included in ITT university-led trajectory.
\end{abstract}

Key words: ITT, QTS, university-led teacher training, integrated Master.

\section{Університетські програми базової професійної підготовки вчителів у Великій Британії}

\author{
Дернова М. Г., Перевознюк В. В. \\ Кременчуцький національний університет імені Михайла Остроградського, Кременчук, Україна
}

\begin{abstract}
Анотація. Стаття присвячена сучасній системі професійної підготовки вчителя у Великій Британії, яка $€$ досить розгалуженою через велику кількість освітніх програм, які ведуть до присудження статусу кваліфікованого вчителя. На макрорівні автори виокремлюють три основних траєкторії, за якими ведеться підготовка педагогічних кадрів для початкової та середньої школи, зокрема університетська, шкільна та комбінована. На мікрорівні розглядається університетська траєкторія, яка пропонує освітні програми на першому і другому рівні професійної підготовки вчителя, зокрема програми для освітнього ступеня бакалавра освіти, бакалавра гуманітарних наук, бакалавра природничих наук, бакалавра гуманітарних наук і бакалавра природничих наук із включенням статусу кваліфікованого вчителя, програми для сертифікату або диплому у галузі освіти, сертифікату в галузі освіти, пов'язаного зі зміною спеціалізації, освітнього ступеня інтегрованого магістра зі статусом кваліфікованого вчителя. У статті також висвітлені вимоги для зарахування до освітніх програм першого і другого рівня. Аналіз освітніх програм британських університетів також дозволив авторам виокремити три типи гнучких програм підготовки вчителів на другому освітньому рівні, а саме: гнучкі, part-time та дистанційні програми для отримання сертифікату у галузі освіти. Зазначено, що для осіб віком понад 21 рік та тих, хто планує навчатися за однією з гнучких програм підготовки вчителя, існує система визнання попереднього досвіду. Аналіз вітчизняних і зарубіжних досліджень системи базової професійної підготовки вчителів виявив, що вони приділяють увагу різним аспектам даної проблеми, але не висвітлюють сучасні програми підготовки вчителів, які з'явилися за останні декілька років, адже система британської освіти постійно трансформується, намагаючись задовольнити мінливі потреби суспільства. У ході дослідження була
\end{abstract}

\footnotetext{
Corresponding Author: Perevozniuk Viktoriia Vadymivna. Tel. 0505889803. E-mail: viktoriaperevozniuk@gmail.com Kremenchuk Mykhailo Ostrohradskyi National University,

20, vul. Pershotravneva, Kremenchuk, Poltava region, Ukraine, 39600.

Відповідальний автор: Перевознюк Вікторія Вадимівна. Тел. 0505889803. E-mail: viktoriaperevozniuk@gmail.com Кременчуцький національний університет імені Михайла Остроградського, вул. Першотравнева, 20, м. Кременчук, Полтавська обл., Україна, 39600.
} 
розглянута та уточнена сучасна університетська траєкторія професійної підготовки вчителів Великобританії. Під уточненням сучасної системи автори розуміють включення до першого і другого рівнів підготовки вчителів нових навчальних програм, які не були висвітлені у попередніх дослідженнях, оскільки з'явилися в останні роки (бакалавр та інтегрований магістр зі включенням статусу QTS).

Ключові слова: ITT підготовка, статус кваліфікованого вчителя, університетська підготовка вчителя, інтегрований магістр.

\title{
Университетские программы базовой профессиональной подготовки учителей в Великобритании
}

\author{
Дернова М. Г., Перевознюк В. В. \\ Кременчугский национальный университет имени Михаила Остроградского, Кременчуг, Украина
}

\begin{abstract}
Аннотация. Статья посвящена современной системе профессиональной подготовки учителя в Великобритании, которая является достаточно разветвленной из-за большого количества образовательных программ, ведущих к присуждению статуса квалифицированного учителя. На макроуровне авторы выделяют три основных траектории, по которым ведется подготовка педагогических кадров для начальной и средней школы, в частности университетская, школьная и комбинированная. На микроуровне рассматривается университетская траектория, которая предлагает образовательные программы на первом и втором уровне профессиональной подготовки учителя, в частности программы для образовательной степени бакалавра педагогики, бакалавра гуманитарных наук, бакалавра естественных наук, бакалавра гуманитарных наук и бакалавра естественных наук с включением статуса квалифицированного учителя, программы для сертификата или диплома в области образования, сертифріката в области образования для изменения специалізации, образовательной степени интегрированного магистра со статусом квалифицированного учителя. В статье также освещены требования для зачисления на образовательные программы первого и второго уровня. Анализ образовательных программ британских университетов также позволил авторам выделить три типа гибких программ подготовки учителей на втором образовательном уровне, а именно: гибкие, part-time и дистанционные программы для получения сертификата в области образования. Отмечено, что для лиц старше 21 года и тех, кто планирует учиться по одной из гибких программ подготовки учителя, существует система признания предыдущего опыта. Анализ отечественных и зарубежных исследований системы базовой профессиональной подготовки учителей обнаружил, что они уделяют внимание различным аспектам данной проблемы, но не освещают современные программы подготовки учителей, которые появились за последние несколько лет, ведь система британского образования постоянно трансформируется, пытаясь удовлетворить меняющиеся потребности общества . В ходе исследования была рассмотрена и уточнена современная университетская траектория профессиональной подготовки учителей Великобритании. Под уточнением современной системы авторы понимают включение в первый и второй уровни подготовки учителей новых учебных программ, которые не были освещены в предыдущих исследованиях, так как появились в последние годы (бакалавр и интегрированный магистр с включением статуса QTS).
\end{abstract}

Ключевые слова: ITT подготовка, статус квалифицированного учителя, университетская подготовка учителя, интегрированный магистр.

\section{Bcmyn}

Шлях європейської інтеграції, яким прямує Україна, зумовлює необхідність інтенсивних змін в економічному, соціальному й політичному житті країни, тому модернізація вітчизняної галузі освіти спрямована на досягнення рівня кращих світових стандартів. Водночас Національна доктрина розвитку освіти України визначає стратегію досягнення нового типу гуманістично-інноваційної освіти, конкурентоздатності у європейському та світовому просторах та виховання професійно мобільного молодого покоління, здатного здійснювати особистісний духовно-світоглядний вибір.

у цих умовах особливої актуальності набувають порівняльно-педагогічні дослідження, які вивчають передовий зарубіжний досвід освіти. Вивчення стану і шляхів динамічного розвитку європейських систем освіти дає підстави стверджувати, що у рамках Болонського процесу відбуваються уніфікація національних освітніх стандартів, диверсифікація моделей освіти та удосконалення освітніх технологій. Особливе місце серед пріоритетних завдань сучасної освіти належить підготовці вчителів, оскільки вчитель завжди був, є і залишається головною особою, яка реалізує їі цілі. Певний науковий інтерес представляє Велика Британія, де склалася й ефективно функціонує багатоступенева система підготовки педагогічних кадрів, про що свідчать роботи відомих британських дослідників, зокрема таких 
як Дж. Евіс, Н. Лукас, Я. Ментер, Т. Муттон, Дж. Мюррей, Р. Томпсон, Р. Фішер, Д. Фостер та інші. Саме у цій країні за останнє десятиліття з'явився цілий ряд принципово нових шляхів професійної підготовки вчителя. Це викликає певний інтерес дослідників у галузі вітчизняної педагогічної освіти. Зокрема, В. Базуріна, О. Леонтьєва, А. Парінов, А. Сбруєва та Н. Яцишин досліджували історію та сучасні трансформаційні зміни у системі педагогічної освіти; реформування вищої педагогічної освіти в Англії; професійну педагогічну підготовку вчителів у Великій Британії; підготовку і перепідготовку вчителів іноземних мов Великої Британії, формування педагогічної майстерності вчителів у Англії та Уельсі. Сучасну реформу вищої педагогічної освіти у Великій Британії досліджували такі вчені як Н. Авшенюк та Ю. Кіщенко. Втім сучасна професійна підготовки вчителів у британських університетах потребує більш детального дослідження, оскільки система педагогічної освіти у цій країні постійно удосконалюється, що призводить до появи нових програм і траєкторій.

Meта роботи: розглянути і охарактеризувати сучасну систему професійної підготовки вчителя у Великій Британії, більш детально дослідити програми університетської траєкторії підготовки вчителя.

\section{II Матеріал і методи дослідження}

Перш за все, відповідно до державного законодавства Великої Британії, статус кваліфікованого вчителя (Qualified teacher status, QTS) вважається необхідною умовою для отримання посади вчителя у школі [10]. Щоб отримати статус QTS, потрібно пройти базову підготовку вчителів (ITT) [7]. Завершення ITT підготовки призводить до отримання статусу QTS в Англії та Уельсі, а також кваліфікації вчителя (TQ) у Шотландії. Відповідальність за присудження статусу QTS покладено на Агентство з управління педагогічною діяльністю (Teaching Regulation Agency, TRA). Рекомендувати кандидатів для QTS мають право тільки акредитовані провайдери ITT підготовки, які, у свою чергу, керуються державними стандартами, що визначають рівень практики і поведінки для вчителів [11], а також рекомендаціями Департаменту освіти, зокрема Програмою основного контенту для ITT підготовки, розробленою у 2016 році [1].

Аналіз системи вищої педагогічної освіти у Великій Британії свідчить, що наразі існує три траєкторії професійної підготовки вчителів - академічна університетська (university-led), шкільна (schoolled) та комбінована (school-and-HE-led) (рис. 1). Університетська - орієнтована на ґрунтовну теоретичну або науково-практичну підготовку в рамках першого та другого ступенів вищої професійної освіти (бакалаврат та магістратура). У шкільній - формування майбутнього вчителя відбувається у процесі роботи в школі, застосовуючи дослідницький підхід до педагогічної діяльності. У комбінованій навчання організоване на партнерських засадах між університетом та школою, де студенти проходять педагогічну практику [27].

Слід зазначити, що Департамент освіти використовує статистичну модель постачання вчителів, щоб оцінити необхідну кількість студентів з кожного предмету на один рік заздалегідь. Ці оцінки використовуються для розподілу навчальних місць серед ITT провайдерів та провідних шкіл, які беруть участь у програмі School Direct [8].

Аналіз статистичних даних свідчить, що понад 30000 осіб обирають один з декількох шляхів підготовки вчителя щороку. Водночас політика британського уряду в останні декілька років спрямована на широке впровадження використання маршрутів підготовки вчителя на базі школи. Відповідно до цього, загальною тенденцією стало збільшення кількості студентів, що обирають шкільну траєкторію підготовки до професійної діяльності вчителя. Так у 2017 - 2018 роках близько 53\% з 27000 осіб навчалися за програмами шкільної траєкторії підготовки вчителів. Тому деякі британські парламентарі вважають, що концентрація уваги на шкільних маршрутах може привести до негативних наслідків університетську траєкторію підготовки вчителів. Тому у відповідь на це британський уряд ще у 2015 році заявив, що шкільна траєкторія підготовки вчителів не означає скасування або зменшення пропозиції університетів, і акцентував увагу на співпраці між школами та університетами з більшості курсів [24]. Виважена політика уряду дає можливість британським університетам тримати свої позиції у підготовці вчителів, про що свідчить той факт, що частка зарахованих до університетських програм ITT підготовки другого рівня склала 47\% [9]. 


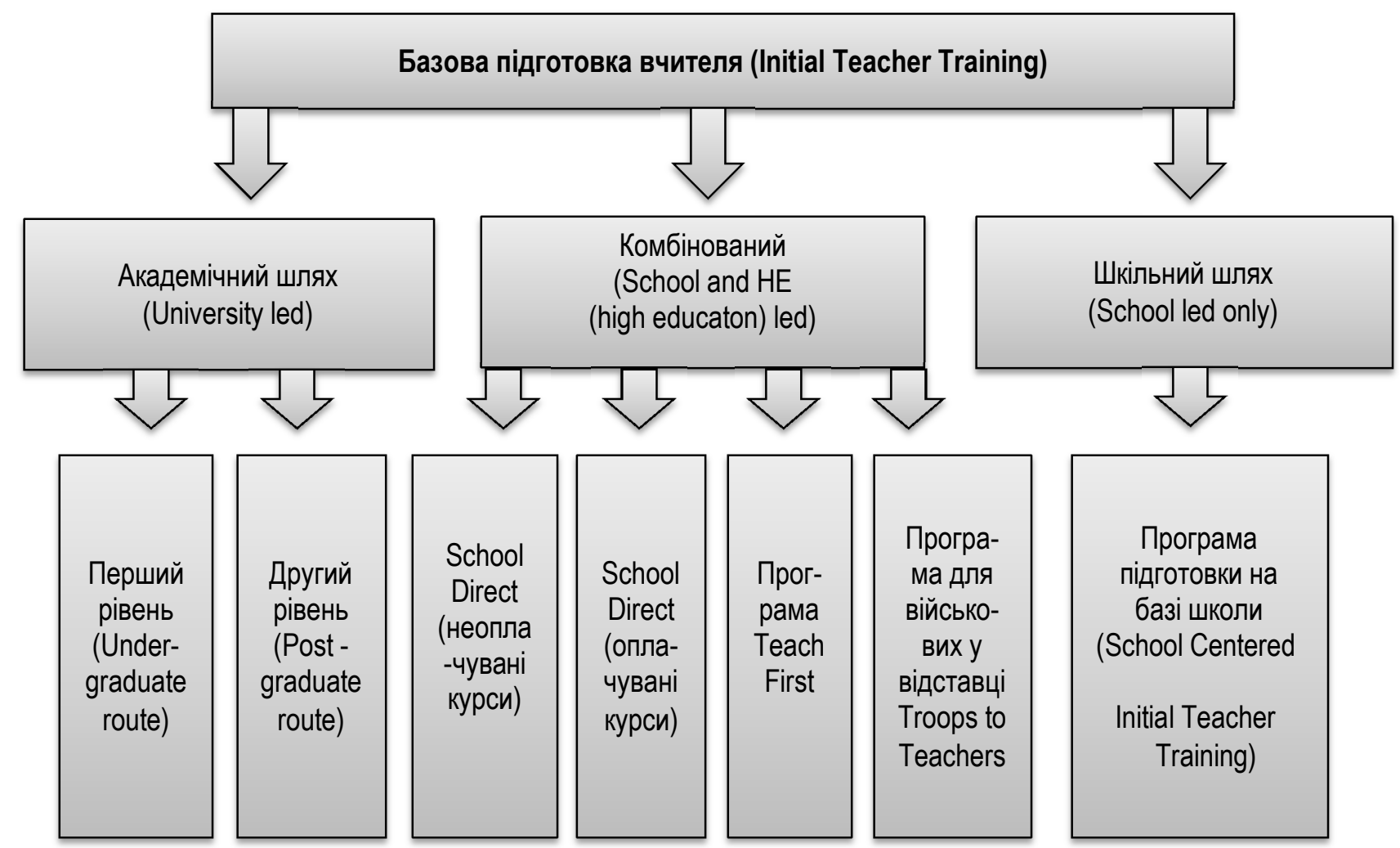

Рис. 1. Траєкторії професійної підготовки вчителів (Initial Teacher Training routes) в університетах Великої Британії

Слід зазначити, що університетська траєкторія педагогічної освіти реалізується не тільки педагогічними відділеннями, факультетами або коледжами при університетах, а й незалежними коледжами (independent colleges) та інститутами вищої освіти (colleges of higher education). Три найбільших університети (університет Сазерленд, Кентерберійський і Ліверпуля) пропонують близько чверті всіх освітніх програм педагогічного профрілю, що дозволяють отримати ступінь бакалавра і статус кваліфікованого вчителя.

Для зарахування до ITT університетських програм першого рівня, необхідно мати диплом загальної середньої освіти (GCSE), іспит з англійської мови та математики з результатом не нижчим ніж C / 4. Для навчання дітей у віці від трьох до одинадцяти років (молодші та початкові класи), необхідно також мати бал за іспит з природознавчого предмету не нижчий ніж $C$ / 4. Ще однією умовою до вступу $\epsilon$ проходження тестів на професійні навички (з математики та граматики) [23]. Для зарахування до ITT університетських програм другого рівня, крім зазначених вимог, необхідно мати освітній ступінь першого рівня [22]. Між іншим, для осіб віком понад 21 рік та тих, хто планує навчатися за однією з гнучких програм підготовки вчителя, існує система визнання попереднього досвіду.

\section{III Результати}

Університетські програми першого рівня ведуть до присудження освітнього ступеня бакалавра гуманітарних, природничих або освітніх наук, а в багатьох випадках, після вдалого закінчення інтегрованого курсу навчання, що поєднує професійно-предметну підготовку й педагогічну практику, статусу QTS. Серед програм цього типу в університетах Великої Британії можна виокремити наступні (рис. 2):

1. Ступінь бакалавра освіти (Bachelor of Education або BEd) - курс навчання в педагогічному коледжі при університеті, орієнтований на предметну спеціалізацію. Програми BEd зазвичай тривають три роки і є популярним маршрутом для майбутніх вчителів початкових класів. Деякі провайдери пропонують програми BEd для середньої школи.

2. Ступінь бакалавра гуманітарних наук (Bachelor of Arts) або бакалавра природничих наук (Bachelor of Science) зі статусом QTS - три- або чотирирічний повний курс, який дуже популярний серед 
майбутніх учителів середніх шкіл. Як правило, студенти глибоко вивчають обрану ними спеціалізацію упродовж першого року навчання. Другий та третій роки навчання спрямовані на здобуття шкільного досвіду, щоб підготувати майбутнього вчителя до робочого місця. Практика роботи в школі здійснюється наприкінці курсу, так що студенти, які усвідомили, що їм не підходить професія вчителя, можуть відмовитися від педагогічної кар'єри і завершити свою освіту за обраною спеціалізацією.

3. Ступінь бакалавра з включенням статусу кваліфікованого вчителя (opt-in QTS) - це нова освітня програма, яка дозволяє студентам освітніх програм для BA та BSc включити педагогічну підготовку до змісту навчання і отримати ступінь за своїм предметом та рекомендації для присудження статусу QTS. Цей шлях займає від трьох до чотирьох років. Він доступний для певних дисциплін, а також у певній кількості університетів, серед них університет Портсмаусу (програма ВА з французької, іспанської та німецької мови, BSc з інформатики), університет Хал (BSc 3 фрізики), університет Манчестера (ВА з французької та іспанської мови), університет Рідінга та університет Сазерленда (ВА сучасних іноземних мов) [5]. Цей курс призначений лише для вчителів середньої школи [23].

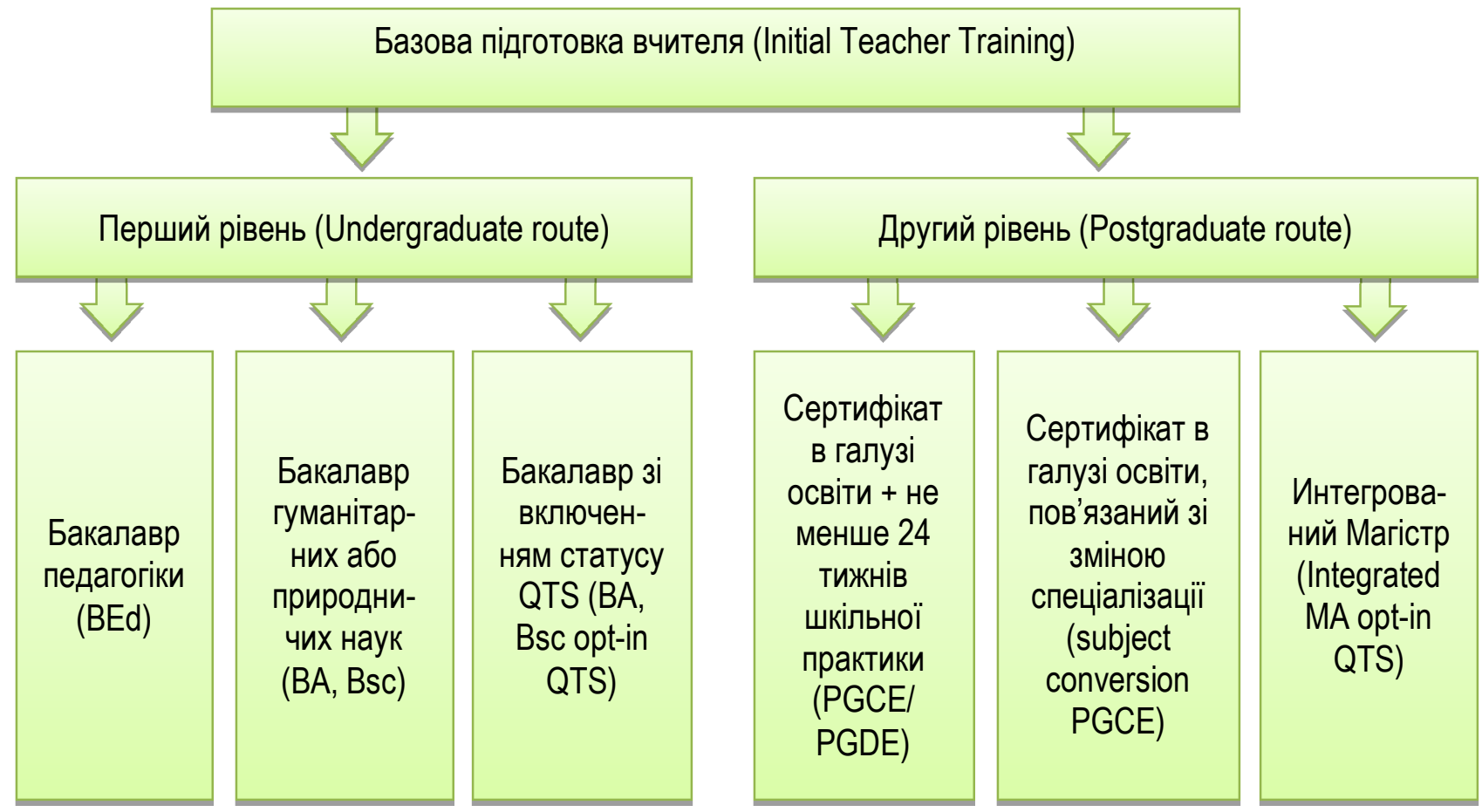

Рис. 2. Академічний шлях (University led route) професійної підготовки вчителів в університетах Великої Британії

Аналіз британських джерел з ITT підготовки вчителів дає нам можливість виокремити наступні програми другого рівня:

1. Сертифікат або диплом в галузі освіти (Postgraduate Certificate in Education, PGCE Postgraduate Diploma in Education, PGDE). PGCE або PGDE - ці дві кваліфікації $є$ одними 3 найпопулярніших шляхів до професійної діяльності вчителя. PGCE - сертифікат в галузі освіти в Англії, Північній Ірландії та Уельсі; PGDE - Диплом в галузі освіти у Шотландії. Ці освітні програми пропонуються багатьма університетами і коледжами Великої Британії. Для роботи у початковій школі потрібен загальний PGCE або PGDE, а для роботи у середній школі - необхідно отримати PGCE або PGDE зі спеціального предмету. Курси тривають рік за денною формою навчання, або два роки раrttime. Навчання здійснюється після отримання ступеня бакалавра гуманітарних або природничих наук. Зазвичай даний курс орієнтований на підготовку вчителя середньої школи [25].

2. Сертифікат в галузі освіти - це дворічна програма, пов'язана зі зміною спеціалізації (Two-year full-time subject conversion PGCE courses). Курс розрахований на тих, хто хоче викладати предмет, який не $є$ його предметом спеціалізації. 
3. Інтегрований магістр (MA opt-in QTS). Метою програми є підготовка випускників, які матимуть повне і системне розуміння сфрери спеціалізації, одночасно отримуючи статус кваліфікованого вчителя QTS, що дозволить студентам, які успішно закінчили програму, розпочати кар'єру вчителя з предмету їх спеціалізації у середній школі або кар'єру фрахівця у сфері спеціалізації [20].

Слід зазначити, що однією з особливостей університетських програм професійної освіти у Великій Британії $€$ широка варіативність в питаннях вибору профілю навчання. Більшість програм містять два рівнозначних профіля і ведуть до присудження подвійного ступеня, деякі - навіть потрійного, а у деяких - педагогічні науки є єдиним напрямом підготовки. Зазначимо, що у більшості випадків у якості другого профрілю виступають обов'язкові й основні предмети Національного шкільного навчального плану (англійська мова, математика, природничі науки, географія, історія, суспільствознавство, іноземні мови, мистецтво і дизайн, музика, інфрорматика, дизайн і технологія, фізичне виховання, а також такі академічні дисципліни як фрілософфія, психологія і соціологія) [21].

На наш погляд, таке різноманіття вибору, з одного боку, пояснюється високою конкуренцією серед університетів та спробами привабити абітурієнтів, які не орієнтовані на кар'єру вчителя, а, 3 іншого, свідчить про універсальність і затребуваність педагогічних знань у різних галузях професійної діяльності сучасної людини. Підкреслимо, що подібні поєднання профрілів характерні для освітніх програм академічної університетської моделі, яка орієнтована на поглиблене вивчення фундаментальних дисциплін і не передбачає вузької спеціалізації на рівні бакалаврату.

Досліджуючи різні програми університетської траєкторії підготовки вчителів на вебсайтах британських університетів, нами виявлено, що університети пропонують ряд гнучких програм на другому рівні підготовки вчителів. Слід зазначити, що у широкому розумінні гнучкість передбачає як просторові, так і часові зміни, які дозволяють студентам мати доступ до вищої освіти в різних місцях, режимах і часових рамках, що відповідають потребам і можливостям індивідів, а не університетів. Це поняття також включає механізми, які дозволяють скоротити термін навчання, наприклад визнання і акредитація попереднього навчання, програми самостійного навчання тощо [19]. Втім загальновизнане визначення гнучкого навчання передбачає, що установа надає студентам гнучкий доступ до навчання 3 точки зору хоча б одного з наступних чинників: час, місце, темп, стиль, зміст, оцінювання та режим навчання. Це визначення ґрунтується на тому, що навчання вимагає активної участі студентів, їх автономності і відповідальності за своє навчання. Тобто, гнучке навчання можна вважати особистісноорієнтованим. Інші характеристики гнучкого навчання включають в себе: взаємодію студентів 3 одногрупниками або працівниками на робочому місці, повне забезпечення ресурсами, контекстність навчання, більший акцент на загальних навичках (наприклад, мислення, мета-пізнання, рішення проблем тощо), а також зміну ролі викладача з джерела знань на фасилітатора впродовж усього періоду навчання студентів [3].

Одним з ключових понять у концепції гнучкості вищої освіти вважається part-time навчання, яке має різні конотації та інтерпретації. Агенція зі статистики вищої освіти Сполученого Королівства [12] визначає part-time студентів як таких, що мають офіційний статус part-time студентів, або які навчаються за програмою коротшою, ніж 24 тижні на рік, за рахунок навчальної відпустки або відвідують заняття у вечірній час.

Отже, серед гнучких освітніх програм підготовки вчителя на другому рівні у британських університетах слід виокремити основні три:

1. Гнучкі програми для сертифікату в галузі освіти (Flexible PGCE programme) - пропонують поєднання дистанційного навчання (теоретична частина), практичних занять на базі університету (1-2 дні на тиждень) і професійної діяльності у школі. Подібна програма з успіхом застосовується в підготовці вчителів середніх шкіл в університеті Едж Хілл (Edge Hill University). Гнучка програма має ті ж вимоги та очікування, що й денна, але існують певні відмінності, зокрема: зарахування до гнучкої програми відбувається упродовж року (тричі на рік); студенти гнучкої програми не можуть проходити професійну практику одночасно зі студентами денної програми (кожен студент має індивідуальний план навчання, який узгоджується з наставником навчальної програми щодо початку професійної практики); можна пройти у режимі part-time; студенти можуть навчатися на відстані (дистанційно) [4].

2. Part-time програми для сертифікату в галузі освіти (Part-time PGCE programme), які тривають два роки. Під час навчання студенти беруть участь в університетських семінарах та тьюторіалах, де 
мають повну підтримку менторів, тьюторів та одногрупників; проходять практику у школі упродовж 24 тижнів, поступово беручи на себе повну відповідальність за заняття у класі. Прикладом такої програми може служити поетапна програма підготовки вчителів для середніх шкіл (staged programme) коледжу Голдсмітс Лондонського університету (Goldsmiths University of London), що передбачає послідовне проходження трьох модулів (двох профрільних, одного загальнопрофесійного) і трьох блоків педагогічної практики [6].

3. Дистанційні програми для сертифрікату в галузі освіти, що повністю реалізуються у віртуальному освітньому просторі університету, а педагогічна практика, як правило, проходить у школах-партнерах. Прикладом може бути Нортумбрійскій університет з його дистанційною програмою підготовки вчителів початкових класів [26].

Особливістю цих програм є індивідуальний підхід до планування, організації освітнього процесу, контролю й оцінювання навчальних результатів. Вони не мають єдиної дати завершення, оскільки терміни навчання безпосередньо залежать від активності слухачів і варіюються від одного року до двох років. Втім ці програми надають можливість широким верствам населення отримати педагогічну освіту другого рівня і розпочати кар'єру вчителя.

\section{IV Обговорення}

Аналіз вітчизняних [28] і зарубіжних [2; 15; 16, 17; 18; 29] досліджень системи базової професійної підготовки вчителів виявив, що вони приділяють увагу різним аспектам даної проблеми, але не висвітлюють сучасні програми підготовки вчителів, які з'явилися за останні декілька років, адже система британської освіти постійно трансфрормується, намагаючись задовольнити мінливі потреби суспільства. Так, наприклад, програми для отримання освітнього ступеня бакалавра та магістра зі включенням статусу кваліфікованого вчителя (opt-in QTS) - це нові програми, які пропонують досить невелика кількість провайдерів (університетів Англії та Уельсу). Цей різновид програм професійної підготовки вчителів Великої Британії не було зазначено в жодному з попередніх досліджень, але він $є$ досить перспективним, оскільки надає можливість випускникам обирати кар'єрний шлях або викладача середньої школи або фахівця за обраною спеціалізацією..

\section{V Висновки}

Розглянувши сучасні траєкторії базової підготовки вчителя у Великій Британії, ми можемо зробити висновок про те, що освітня політика уряду цієї країни зосереджена на створенні умов для суспільства, що навчається. Тому модель базової підготовки вчителів досить диверсифрікована і гнучка, що сприяє задоволенню потреб студентів різного віку, з різним освітнім та професійним досвідом, i, як наслідок, задоволенню потреби у якісних педагогічних кадрах.

У ході дослідження була розглянута та уточнена сучасна університетська траєкторія (Universityled route) профресійної підготовки вчителів Великобританії. Під уточненням сучасної системи ми розуміємо включення до першого і другого рівнів підготовки вчителів нових навчальних програм, які не були висвітлені у попередніх дослідженнях, адже з'явилися в останні роки (бакалавр та інтегрований магістр зі включенням статусу QTS (BA, BSc, MA opt-in QTS). Перспективою подальшого дослідження вбачаємо аналіз програм підготовки вчителів за шкільною та комбінованою траєкторіями у системі ITT підготовки у Великій Британії.

\section{Бібліографрічні посилання}

[1] A framework of core content for initial teacher training (ITT) July $2016 . \quad$ URL: https://assets.publishing.service.gov.uk/government/uploads/system/uploads/attachment_data/file/536890/Framework_Repo rt_11_July_2016_Final.pdf (дата звернення 10.10.2018).

[2] Avis, J., Fisher, R. and Thompson, R. (2010) Teaching in Lifelong Learning: A guide to theory and practice. Maidenhead: Open University Press.

[3] Chen, D-T. (2003) Uncovering the provisos behind flexible learning. Educational Technology \& Society. 6 (2), pp. 25-30

[4] Flexible Post Graduate Professional Graduate Certificate in Education. Professional Practice Handbook $22015-2016$. Edgehill University. URL: https://www.edgehill.ac.uk/ educationpartnership/files/ 2014/09/PGCE-Flexible-ProfessionalPractice-2-Handbook-2015-16.pdf (дата звернення 10.10.2018). 
[5] Get into teaching with support and advice from the Department for Education. Degrees with opt-in QTS. URL: https:/getintoteaching.education.gov.uk/ explore-my-options/ teacher-training-routes/university-led-training/ university-ledundergraduate-training/degrees-with-opt-in-qts (дата звернення 10.10.2018).

[6] Goldsmiths University of London. PGCE (Secondary) Part-Time Programme. URL: http://www.gold.ac.uk/ pgce/secondaryflexible/ (дата звернення 10.10.2018).

[7] Government UK portal. Initial teacher training (ITT): criteria and supporting advice. URL: https://www.gov.uk/government/ publications/initial-teacher-training-criteria (дата звернення 10.10.2018).

[8] Government UK portal. Initial teacher training: trainee number census - 2018 to 2019. URL: https://www.gov.uk/ government/ statistics/ initial-teacher-training-trainee-number-census-2018-to-2019 (дата звернення 10.10.2018).

[9] Government UK portal. Initial teacher training: trainee number census - 2017 to 2018 . URL: https://www.gov.uk/ government/ statistics/ initial-teacher-training-trainee-number-census-2017-to-2018 (дата звернення 10.10.2018).

[10] Government UK portal. Qualified teacher status (QTS): qualify to teach in England. URL: https://www.gov.uk/ guidance/ qualified-teacher-status-qts (дата звернення 10.10.2018).

[11] Government UK portal. Teachers' Standards URL: https://www.gov.uk/ government/ publications /teachers-standards (дата звернення 10.10.2018).

[12] Higher Education Statistics Agency. Definishions: Students: Mode of study. URL: https://www.hesa.ac.uk/ support/ definitions/students (дата звернення 10.10.2018).

[13] Houston, M., McCune, V., and Osborne, M. (2011) Flexible learning and its contribution to widening participation: a synthesis of research. Project Report. Higher Education Academy

[14] Initial Teacher Education for Education and Training Sector in England: development and Change in Generic and Subject-Specialist Provision. A Report by Ron Thompson School of Education and Professional Development University of Huddersfield (2014) URL: http://www.gatsby.org.uk/uploads/education/reports/pdf/initial-teacher-education-for-the-education-and-training-sector.pdf (дата звернення 10.10.2018).

[15] Menter, I., Hulme, M., Elliot, D. and Lewin, J. (2010) Literature Review on Teacher Education in the 21st Century, Edinburgh: The Scottish Government.

[16] Menter, lan (2017) The Role and Contribution of Higher Education in Contemporary Teacher Education. Scottish Council of Deans of Education. URL: http://www.scde.ac.uk/ wp-content/uploads/ 2017/05/Report-lan-Menter-2017-05-25.pdf (дата звернення 10.10.2018).

[17] Murray, J. (2016) 'Teacher education and higher education'. In Teacher Education Group, Teacher Education in Times of Change. Bristol: Policy Press. pp. 179-200.

[18] Murray, J. and Mutton, T. (2016) 'Teacher education in England: change in abundance, continuities in question'. In Teacher Education Group, Teacher Education in Times of Change. Bristol: Policy Press. pp. 57-74.

[19] Osborne, M. (2006) Flexibility and Widening Participation. In: Osborne, M. and Young, D. (eds.) Flexibility and Widening Participation, Part 1. York: HEA.

[20] Programme Specification Joint Integrated Masters. University of Liverpool. URL: https://www.liverpool.ac.uk/ media/livacuk/ tqsd/ programmespecs/ Computer,Science,with,QTS,MEng.pdf (дата звернення 10.10.2018).

[21] The National Curriculum in England URL: https://assets.publishing.service.gov.uk/ government/uploads/ system/uploads/ attachment_data /file/425601/ PRIMARY_national_curriculum.pdf (дата звернення 10.10.2018).

[22] UCAS. PGCE university-led teacher training. URL: https://www.ucas.com/ teaching-option/ pgce-university-led-teachertraining (дата звернення 10.10.2018).

[23] UCAS. Undergraduate teacher training in England. URL: https://www.ucas.com/ postgraduate/ teacher-training/ train-teachengland/ undergraduate-teacher-training-england (дата звернення 10.10.2018).

[24] UK Parliament. House of Lords. Teacher Training.04 November 2015, Volume 765. URL: https://hansard.parliament.uk/Lords/2015-11-04/debates/15110439000439/TeacherTraining (дата звернення 10.10.2018).

[25] University led training - PGCE/PGDE. The Complete University Guide. URL: https://www.thecompleteuniversityguide.co.uk/how-to-get-into-teaching/postgraduate-routes/university-led-training/ (дата звернення 10.10.2018).

[26] University of Northumbria at Newcastle. PGCE Early Primary Education. URL: https://www.northumbria.ac.uk/study-atnorthumbria/courses/pgce-early-primary-education-blended-learning-gtpype6/ (дата звернення 10.10.2018).

[27] Williams J., Pollard E., Hinks R., Huxley C., Marvel R. The customer journey to initial teacher training Research report. Institute for Employment Studies, 2016. URL: https:// assets.publishing.service.gov.uk/ government/uploads/system/ uploads/attachment_data/file/530894/RR502_Customer_Journey_to_initial_teacher_training.pdf (дата звернення 10.10.2018).

[28] Зарубіжний досвід професійної підготовки педагогів : аналітичні матеріали / [Авшенюк Н.М., Дяченко Л.М., Котун К.В., Марусинець М.М., Огієнко О.І., Сулима О.В., Постригач Н.О.]. Київ : ДКС «Центр», 2017. 83 с.

[29] Новикова Ю. Б. Практико-ориентированный подход к профессиональной подготовке Британского учителя (конец XX - начало XXI в.в.): авторефр. дис. ... канд. пед.наук. M., 2014. URL: http://nauka-pedagogika.com/ pedagogika-13-00-01/ dissertaciya-praktiko-orientirovannyy-podhod-k-professionalnoy-podgotovke-britanskogo-uchitelya (дата звернення 10.10.2018). 


\section{References}

[1] A framework of core content for initial teacher training (ITT) July 2016. URL: https://assets.publishing.service.gov.uk/ government/ uploads/ system/uploads/ attachment_data/file/ 536890/Framework_Report_11_July_2016_Final.pdf (accessed 10.10.2018).

[2] Avis, J., Fisher, R. and Thompson, R. (2010). Teaching in Lifelong Learning: A guide to theory and practice. Maidenhead: Open University Press.

[3] Chen, D-T. (2003). Uncovering the provisos behind flexible learning. Educational Technology \& Society. 6 (2), pp. 25-30.

[4] Flexible Post Graduate Professional Graduate Certificate in Education. Professional Practice Handbook 2 2015-2016. Edgehill University. URL: https:/www.edgehill.ac.uk/educationpartnership/ files/2014/09/ PGCE-Flexible-ProfessionalPractice-2-Handbook-2015-16.pdf (accessed 10.10.2018).

[5] Get into teaching with support and advice from the Department for Education. Degrees with opt-in QTS. URL https://getintoteaching.education.gov.uk/ explore-my-options/teacher-training-routes/ university-led-training/university-ledundergraduate-training/degrees-with-opt-in-qts (accessed 10.10.2018).

[6] Goldsmiths University of London. PGCE (Secondary) Part-Time Programme. URL: http://www.gold.ac.uk/ pgce/ secondaryflexible/ (accessed 10.10.2018).

[7] Government UK portal. Initial teacher training (ITT): criteria and supporting advice. URL https://www.gov.uk/ government/ publications/ initial-teacher-training-criteria (accessed 10.10.2018).

[8] Government UK portal. Initial teacher training: trainee number census - 2018 to 2019. URL: https://www.gov.uk/ government/ statistics/ initial-teacher-training-trainee-number-census-2018-to-2019 (accessed 10.10.2018).

[9] Government UK portal. Initial teacher training: trainee number census - 2017 to 2018. URL: https://www.gov.uk/ government/ statistics/ initial-teacher-training-trainee-number-census-2017-to-2018 (accessed 10.10.2018).

[10] Government UK portal. Qualified teacher status (QTS): qualify to teach in England. URL: https://www.gov.uk/ guidance/ qualified-teacher-status-qts (accessed 10.10.2018).

[11] Government UK portal. Teachers' Standards. URL: https://www.gov.uk/ government/ publications/ teachers-standards (accessed 10.10.2018).

[12] Higher Education Statistics Agency. Definishions: Students: Mode of study. URL: https://www.hesa.ac.uk/ support/definitions/students (accessed 10.10.2018).

[13] Houston, M., McCune, V., and Osborne, M. (2011) Flexible learning and its contribution to widening participation: a synthesis of research. Project Report. Higher Education Academy.

[14] Initial Teacher Education for Education and Training Sector in England: development and Change in Generic and Subject-Specialist Provision. A Report by Ron Thompson School of Education and Professional Development University of Huddersfield (2014). URL: http://www.gatsby.org.uk/ uploads/education/ reports/pdf/ initial-teacher-education-for-the-education-and-training-sector.pdf (accessed 10.10.2018).

[15] Menter, I., Hulme, M., Elliot, D. and Lewin, J. (2010). Literature Review on Teacher Education in the 21st Century, Edinburgh: The Scottish Government.

[16] Menter, lan (2017). The Role and Contribution of Higher Education in Contemporary Teacher Education. Scottish Council of Deans of Education. URL: http://www.scde.ac.uk/ wp-content/uploads/ 2017/05/Report-lan-Menter-2017-05-25.pdf (accessed 10.10.2018).

[17] Murray, J. (2016). 'Teacher education and higher education'. In Teacher Education Group, Teacher Education in Times of Change. Bristol: Policy Press. pp. 179-200.

[18] Murray, J. and Mutton, T. (2016). 'Teacher education in England: change in abundance, continuities in question'. In Teacher Education Group, Teacher Education in Times of Change. Bristol: Policy Press. pp. 57-74.

[19] Osborne, M. (2006). Flexibility and Widening Participation. In: Osborne, M. and Young, D. (eds.) Flexibility and Widening Participation, Part 1. York: HEA.

[20] Programme Specification Joint Integrated Masters. University of Liverpool. URL: https://www.liverpool.ac.uk/ media/livacuk/tqsd/programmespecs/Computer,Science,with,QTS,MEng.pdf (accessed 10.10.2018).

[21] The National Curriculum in England. URL: https:// assets.publishing.service.gov.uk/ government/uploads/ system/uploads/attachment_data/file/425601/PRIMARY_national_curriculum.pdf (accessed 10.10.2018).

[22] UCAS. PGCE university-led teacher training. URL: https:// www.ucas.com/ teaching-option/ pgce-university-led-teachertraining (accessed 10.10.2018).

[23] UCAS. Undergraduate teacher training in England. URL: https:/www.ucas.com/postgraduate/teacher-training/train-teachengland/undergraduate-teacher-training-england (accessed 10.10.2018).

[24] UK Parliament. House of Lords. Teacher Training.04 November 2015, Volume 765. URL: https://hansard.parliament.uk/ Lords/2015-11-04/debates/15110439000439/TeacherTraining (accessed 10.10.2018).

[25] University led training - PGCE/PGDE. The Complete University Guide. URL: https:// www.thecompleteuniversityguide.co.uk/ how-to-get-into-teaching/postgraduate-routes/university-led-training/ (accessed 10.10.2018).

[26] University of Northumbria at Newcastle. PGCE Early Primary Education. URL: https://www.northumbria.ac.uk/study-atnorthumbria/courses/pgce-early-primary-education-blended-learning-gtpype6/ (accessed 10.10.2018).

[27] Williams J., Pollard E., Hinks R., Huxley C., Marvel R. (2016). The customer journey to initial teacher training Research report. Institute for Employment Studies, 2016. URL: https:// assets.publishing.service.gov.uk/ government/uploads/system/ uploads/attachment_data/file/530894/RR502_Customer_Journey_to_initial_teacher_training.pdf (accessed 10.10.2018). 
[28] Aveshenyuk, N. M, Dyachenko, L. M., Kotun, K. V., Marusynets, M. M, Ogienko, O. I, Sulima, O.V., Postryhach, N.O. (2017). Foreign experience of professional training of teachers: analytical materials. DKS "Center", Kyiv, Ukraine, 83 p. [in Ukrainian]

[29] Novikova, Yu.B. (2014). Practical-oriented approach to the professional training of the British teacher (end of XX - beginning of the XXI century): author's abstract. dis ... candidate ped.nauc. URL: http://nauka-pedagogika.com/ pedagogika-13-00-01/ dissertaciya-praktiko-orientirovannyy -podhod-k-professionalnoy- podgotovke-britanskogo-uchitelya (accessed 10.10.2018). [in Russian]

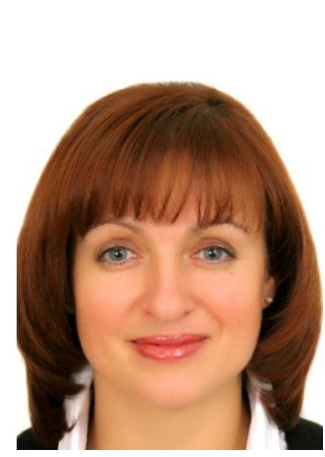

\section{Дернова Майя Григорівна.}

К.пед.н, доцент, Кременчуцький національний університет імені Михайла Остроградського, вул. Першотравнева, 20, 39600 м. Кременчук, Полтавська обл.

Тел. 0679516990. E-mail: maya.dernova@ukr.net

\section{Dernova Maiia Grygorivna.}

Ph.D (Pedagogy), Associate Professor, Kremenchuk Mykhailo Ostrohradskyi National University, 20, vul. Pershotravneva, Kremenchuk, Poltava region, Ukraine, 39600.

Tel. 0679516990. E-mail: maya.dernova@ukr.net

ORCID: 0000-0003-4545-5247

Researcher ID: I-8556-2018

Scopus ID: 57202585768

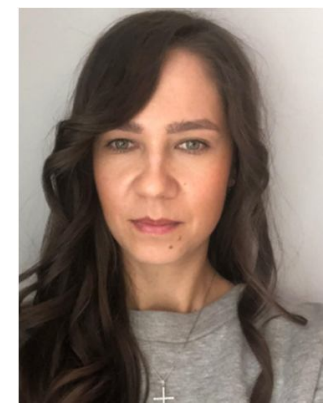

\section{Перевознюк Вікторія Вадимівна.}

Аспірант, викладач, Кременчуцький національний університет імені Михайла Остроградського, вул. Першотравнева, 20, м. Кременчук, Полтавська обл., 39600.

Тел. 0505889803. E-mail: viktoriaperevozniuk@gmail.com

\section{Perevozniuk Viktoriia Vadymivna.}

Ph.D student, Lecturer, Kremenchuk Mykhailo Ostrohradskyi National University, 20, vul. Pershotravneva, 39600, Kremenchuk, Poltava region, Ukraine.

Tel. 0505889803. E-mail: viktoriaperevozniuk@gmail.com

ORCID: 0000-0001-9225-3459

Researcher ID: M-7118-2018

Scopus ID: 57202589898

\section{Citation (APA):}

Dernova, M., Perevozniuk, V. (2018). University-Led Routes of Initial Teacher Training in Great Britain. Engineering and Educational Technologies, 6 (4), 66-75. doi: https://doi.org/10.30929/2307-9770.2018.06.04.07

\section{Цитування (ДСТУ 8302:2015):}

Дернова М. Г., Перевознюк В. В. Університетські програми базової профресійної підготовки вчителів у Великій Британії $/$ Інженерні та освітні технологіï. 2018. Т. 6. № 4. С. 66-75. doi: https://doi.org/10.30929/2307-9770.2018.06.04.07

Обсяг статmі: сторінок - 10 ; умовних друк. аркушів - 1,149. 